\title{
A Comparative Study of Emotional Maturity among Girls and Boys under Graduate Student
}

\author{
Mr. Tribhovan B. Makwana ${ }^{1}$
}

\section{ABSTRACT:}

The present study is a comparative study regarding emotional maturity among girls and boys under graduate student. In this study total 600 student were randomly selected as a sample in the present study. Emotional maturity test constructed by Dr. Mahesh Bhargav and It was used for collection of data t-test method under by in $2 \times 2 \times 3$ factorial design was used for statistical analysis of variable. It can be know by the analysis that $\mathrm{Ho}_{1}$ there is significant difference between emotional maturity among girls and boys under graduate student. $\mathrm{Ho}_{2}$ There is significant different between emotional maturities among rural and urban under graduate student. $\mathrm{Ho}_{3}$ There is significant different between emotional maturity among arts and commerce faculty under graduate student. $\mathrm{Ho}_{4}$ There is significant difference between emotional maturity among arts and Science College under graduate student. $\mathrm{Ho}_{5}$ There is significant difference between emotional maturity among commerce and science faculty under graduate students.

\section{Keywords: Emotional Maturity, Graduate Students}

\section{INTRODUCTION:}

Performance in any endeavors is largely contingent upon mental preparation psychological strength and emotional maturity. Just as one prepares for competition by practicing, physical skill as well as increasing his/her strength and endurance, one must also prepare himself/her self mentally as well as emotionally, Emotional are great motivation forces throughout the span of human life. An emotion involves feelings, impulses and physiological reaction Kaplan and Baron (1986) said there are so many factors which can influence the process of adjustment level of aspiration/socio economics status, family environment, caste, school environment, anxiety, frustration and above all his emotional maturity students is a period where the behavior self influences highly by the emotional. According to Menninger (1999), emotional maturity includes the ability to deal constructively with reality. Emotional maturity is a process in which the personality is continuously striving for greater sense. If emotional health both infra-physically and intra personally.

${ }^{1}$ Research Scholar (Ph.D.) Department of Psychology, Saurastra Uni., Rajkot 
Emotional maturing can be understood in term of ability of which in turn is a result of thinking and learning. Chamberlain (1960) said that an emotionally matured person is one whose emotional life is well under.

\section{OBJECTIVE OF RESEARCH}

1. To get information regarding emotional maturity among girls and boys under graduate student.

2. To get information regarding emotional maturity among rural and urban under graduate student.

3. To get information regarding emotional maturity among arts, commerce and science faculty under graduate student.

\section{HYPOTHESIS OF RESEARCH}

$\mathrm{Ho}_{1}$ There is no significant difference between emotional maturity among girls and boys under graduate student.

$\mathrm{Ho}_{2}$ There is no significant difference between emotional maturity among rural and urban under graduate student.

$\mathrm{Ho}_{3}$ There is no significant difference between emotional maturity among arts and commerce faculty under graduate student.

$\mathrm{Ho}_{4}$ There is no significant difference between emotional maturity among arts and science faculty under graduate student.

Ho5 There is no significant difference between emotional maturity among commerce and science faculty under graduate student.

\section{Variables}

\section{Independence Variable}

$$
\begin{aligned}
& \mathrm{A}=\text { Gender } \quad \mathrm{A}_{1}=\text { Boys } \quad \mathrm{A}_{2}=\text { Girls } \\
& \mathrm{B}=\text { Area } \quad \mathrm{B}_{1}=\text { Rural } \quad \mathrm{B}_{2}=\text { Urban } \\
& \mathrm{C}=\text { Facult } \quad \mathrm{C}_{1}=\text { Arts } \quad \mathrm{C}_{2}=\text { Commerce } \quad \mathrm{C}_{3}=\text { Science }
\end{aligned}
$$

Dependent Variable : Score of Emotional Maturity Scale : 


\section{Sample}

$2 \times 2 \times 3$ factorial design was used for this study sample of the present study consist 600 students 300 boy and 300 girl students of different faculty and areas. Sample were randomly selected from different colleges in Anand.

Tools

Emotional Maturity Scale was used for data collection. Emotional maturity scale was standardizing by Dr. Mahesh Bhargave reliability.

\section{Statistical Analysis}

' $\mathrm{t}$ ' test was used for this research.

\section{Result and Interpretation}

Table-1 shows S.D. Mean, Mean Different, ' $t$ ' value, significant level of emotional maturity of boys and girls under graduate student

\begin{tabular}{|c|c|c|c|c|c|c|c|}
\hline Gender & $\mathbf{N}$ & Mean & $M_{1}-M_{2}$ & SD & $\begin{array}{c}\text { t- } \\
\text { value }\end{array}$ & t-table & $\begin{array}{l}\text { Sign. } \\
\text { Level }\end{array}$ \\
\hline Boys & 300 & 132.84 & \multirow[b]{2}{*}{3.74} & 24.07 & \multirow[b]{2}{*}{1.96} & $1.96(0.05)$ & \multirow[b]{2}{*}{0.05} \\
\hline Girls & 300 & 136.58 & & 22.52 & & $2.58(0.01)$ & \\
\hline
\end{tabular}

\section{Interpretation}

There is no significant difference between emotional maturity among boys and girls student. For testing of this hypothesis ' $t$ ' value can be seen 1.96 in table- 1 . This value is which is significant at 0.05 level. Hence null hypothesis is rejected. Mean score can be seen of boys. Which is 132.84 and S.D. 24.07. This score compared with girls student mean score 136.58 and S.D. 22.52 and mean difference is 3.74. It means there is significant. Thus girls emotional maturity is very compared to boys.

Table-2, Shows S.D., Mean, Mean Different, ' $t$ ' value, significant level of emotional maturity of rural and urban under graduate student.

\begin{tabular}{|c|c|c|c|c|c|c|c|}
\hline Area & $\mathbf{N}$ & Mean & $\mathbf{M}_{\mathbf{1}}-\mathbf{M}_{2}$ & SD & $\begin{array}{c}\text { t- } \\
\text { value }\end{array}$ & t-table & $\begin{array}{c}\text { Sign. } \\
\text { Level }\end{array}$ \\
\hline Rural & 300 & 132.21 & \multirow{2}{*}{4.99} & 22.16 & & $1.96(0.05)$ & \multirow{2}{*}{0.01} \\
\cline { 1 - 2 } & Urban & 300 & 137.2 & 24.28 & 2.62 & $2.58(0.01)$ & 0.01 \\
\hline
\end{tabular}

\section{Interpretation}

There is no significant different between emotional maturity among rural and urban under graduate student for testing of this hypothesis ' $t$ ' value can be seen 2.62 in table-2. This value is which is significant at 0.01 level. Hence null hypothesis is rejected. Mean score can be seen of 
rural under graduate students. Which is 132.21 S.D., 22.16. This score compare to urban under graduate student mean score 137.2, S.D. 24.28 and mean difference 4.99. It means there is significant, thus urban under graduate student emotional maturity is high compare to rural under graduate students.

Table-3 Shows S.D., Mean, Mean Different, ' $t$ ' value, significant level of emotional maturity of Arts and Commerce faculty under graduate student.

\begin{tabular}{|c|c|c|c|c|c|c|c|}
\hline Faculty & $\mathbf{N}$ & Mean & $\mathbf{M}_{\mathbf{1}}-\mathbf{M}_{2}$ & SD & $\begin{array}{c}\mathbf{t}- \\
\text { value }\end{array}$ & t-table & $\begin{array}{c}\text { Sign. } \\
\text { Level }\end{array}$ \\
\hline Arts & 300 & 131.16 & \multirow{3}{*}{4.73} & 23.57 & & $1.96(0.05)$ & \multirow{2}{*}{0.05} \\
\cline { 1 - 2 } & Commerce & 300 & 135.89 & 22.6 & 2.04 & $2.58(0.01)$ & 0.05 \\
\hline
\end{tabular}

\section{Interpretation}

There is no significant different between arts \& commerce faculty under graduate students for testing of this hypothesis ' $t$ ' value can be seen 2.04 in table-3. This value is which is significant at 0.05 level. Hence null hypothesis is rejected. Mean score can be seen of arts faculty under graduate 131.16, S.D. 23.57. This score compare with commerce faculty student means score 135.89, So 22.06 and mean difference is 4.73. It means there is significant. Thus commerce faculty under graduate student emotional maturity is very high compared to arts faculty under graduate students.

Table-4 Shows S.D., Mean, Mean Different, ' $t$ ' value, significant level of emotional maturity of Arts and Science faculty under graduate student.

\begin{tabular}{|c|c|c|c|c|c|c|c|}
\hline Faculty & $\mathbf{N}$ & Mean & $\mathbf{M}_{1}-\mathbf{M}_{2}$ & SD & $\begin{array}{c}\text { t- } \\
\text { value }\end{array}$ & t-table & $\begin{array}{l}\text { Sign. } \\
\text { Level }\end{array}$ \\
\hline Arts & 200 & 131.16 & \multirow[b]{2}{*}{5.91} & 23.57 & \multirow[b]{2}{*}{2.5} & $1.96(0.05)$ & \multirow[b]{2}{*}{0.05} \\
\hline Science & 200 & 137.07 & & 23.6 & & $2.58(0.01)$ & \\
\hline
\end{tabular}

Interpretation

There is no significant different between of emotional maturity among arts \& science faculty under graduate students for testing of this hypothesis ' $t$ ' value can be seen 2.5 in table- 4 . This value is which is significant at 0.05 level. Hence null hypothesis is rejected. Mean score can be seen of arts faculty under graduate student which is 131.16 and S.D. 23.57. This score compare with science faculty undergraduate student means score 137.07, and So 23.5 and mean difference is 5.91. It means there is significant. Thus Science faculty under graduate student emotional maturity is very high compared to arts faculty under graduate students. 
A Comparative Study of Emotional Maturity among Girls and Boys under Graduate Student

Table-5 Shows S.D., Mean, Mean Different, ' $t$ ' value, significant level of emotional maturity of Commerce and Science faculty under graduate student.

\begin{tabular}{|c|c|c|c|c|c|c|c|}
\hline Faculty & $\mathbf{N}$ & Mean & $\mathbf{M}_{1}-\mathbf{M}_{2}$ & SD & $\begin{array}{c}\text { t- } \\
\text { value }\end{array}$ & t-table & $\begin{array}{l}\text { Sign. } \\
\text { Level }\end{array}$ \\
\hline Commerce & 200 & 131.16 & \multirow[b]{2}{*}{4.73} & 23.57 & \multirow[b]{2}{*}{2.4} & $1.96(0.05)$ & \multirow[b]{2}{*}{0.05} \\
\hline Science & 200 & 135.89 & & 22.6 & & $2.58(0.01)$ & \\
\hline
\end{tabular}

Interpretation

There is no significant different between of emotional maturity among Commerce \& science faculty under graduate students for testing of this hypothesis ' $t$ ' value can be seen 2.4 in table- 2 . This value is which is significant at 0.05 level. Hence null hypothesis is rejected. Mean score can be seen of commerce faculty under graduate student which is 131.16 and S.D. 23.57. This score compare with science faculty undergraduate student means score 135.89, and S.D. 22.6 and mean difference is 4.73 . It means there is significant. Thus science faculty under graduate student emotional maturity is very high compared to commerce faculty under graduate students.

\section{CONCLUSION}

1. There is significance difference between emotional maturity among girls and boys under graduate student.

2. There is significance difference between emotional maturity among rural and urban under graduate students.

3. There is significant difference between emotional maturity among arts and commerce faculty under graduate students.

4. There is significant difference between emotional maturity among arts and science faculty under graduate students.

5. There is significant difference between emotional maturity among commerce and science faculty under graduate students.

\section{REFERENCE}

1. Amy G. Halberstalt (1988), Family Socialization of Emotional Expression and Non Verbal Communication Styles and Skills.

2. Boss and Mukhopadhyay (1993), "An Attempt to trace the emotional maturity factor and impact on stress among male and female students."

3. Jansari, A., (1013), "Psychology of Emotion", Akshar Publication, Ahmedabad, Page No. 39.

4. Kaur \& Samunth (1992), "Emotional Status of Institutionalized Aged".

5. Mangal, S.K., (2012), "General Psychology”, Sterling Publication Pvt Ltd., P.No. 73. 